\title{
Assessing and Optimizing the Economy of Distributed Power Generation
}

\author{
Xu Er-Shu, Wang Bing-Shu, Song Zhi-Ping \\ North China Electric Power University, Baoding, Hebei Province, China 071003
}

\begin{abstract}
In the new era of mounting awareness of sustainable development, the distributed power generation is become one of energy system alternatives under consideration. This paper deals with a cost model of distributed power generation. An office building distributed energy system located in Beijing is investigated as a sample of the model. In line with the office building's energy demand profile and the characteristics of Beijing local electric network, an economic feasibility study on the distributed power generation at a competitive electric market structure is presented.
\end{abstract}

Key words: distributed power generation, cost-effectiveness analysis, model

\section{Introduction}

The electricity industry, historically a regulated, vertically integrated business with centralized planning and decision making, is now entering a new chapter in which new emerging technologies for distributed power generation, energy storage, controls, communications, and energy management offer the potentiality for customers to manage their energy use and processes on an integration basis. Customers' need for integrated, cost-effective, timely, and reliable solutions opens up significant investment and business opportunities for new products, services, and the emerging technologies will make the future electric system more efficient, reliable, lower cost, decentralized, and smart.

Distributed power generation or distributed generation (DG) for short is currently understood as small power generation units (typically less than $30 \mathrm{MW}$ ) strategically located near consumers and load centers that provide benefits to customers and support for the economic operation of the existing power distribution grid, whether or not those technologies are connected to an electricity grid. Most types of distributed generators utilize traditional power generation paradigms -- reciprocating engines, small combustion turbine, combined cycle turbine, energy storage. But in addition, DG includes fuel cells, micro turbines and renewable power generation methods such as wind, solar, or low-head hydro generation. Distributed power generation can provide a very wide range of benefits depending on the type of generation deployed where it is installed, and when and how it is operated. Distributed power generation can provide spinning reserve, load following, and reactive power. Properly sited and operated distributed power generation can reduce and defer investment in transmission and distribution plant. When operated in a way that reduces line and transformer loading, distributed power generation can reduce losses. Environmental improvements are likely from renewable based distributed power generation as well as from high efficiency gas-fueled sources.

This paper deals with a cost model of distributed 
power generation. An office building distributed energy system located in Beijing is investigated as a sample of the model. In line with the office building's energy demand profile and the characteristics of Beijing local electric network, an economic feasibility study on the distributed power generation at a competitive electric market structure is presented.

\section{The existing energy supply system of office building}

The office building chosen as the sample case located in Beijing and has a total floor area of $5600 \mathrm{~m}^{2}$. At the moment, the building purchases natural gas for space heating and electricity for lighting, ventilation, air conditioning, water heating, and office equipment. The office building currently relies on an oil-fired diesel engine generation to provide $700 \mathrm{~kW}$ of backup power for the building's security, fire alarm system and emergency lighting. For purpose heating, ventilating, and air conditioning (HVAC) system the building is equipped with two $350 \mathrm{~kW}$ gas-fired boilers and two $630 \mathrm{~kW}$ electrically driven vapor compression water chillers. The HVAC
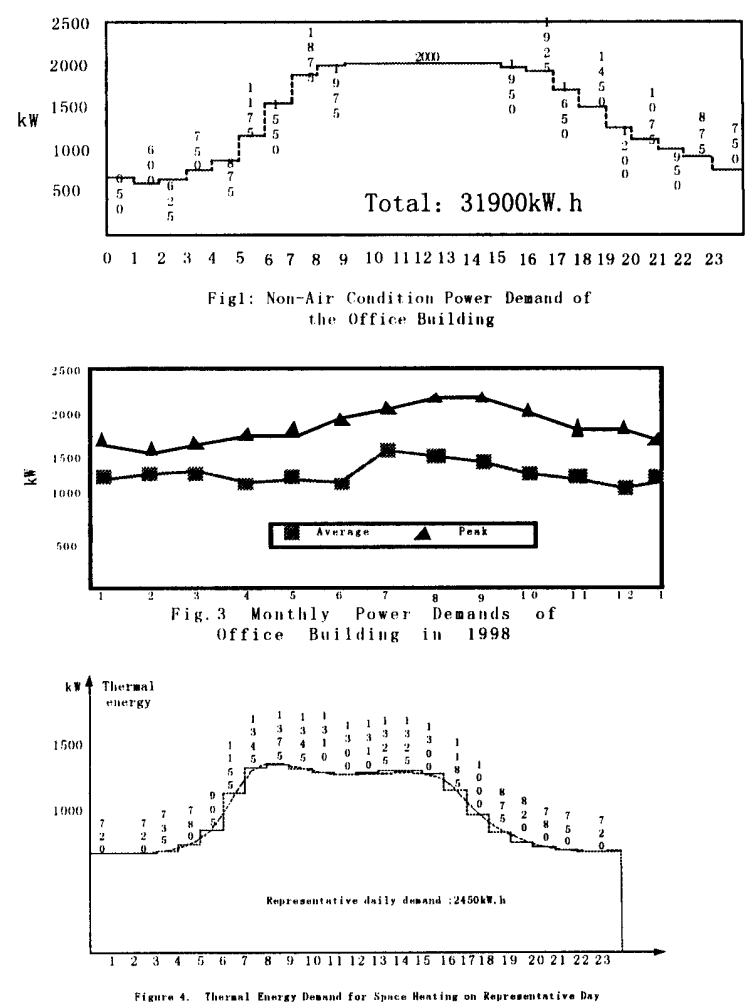

prime movers provide

the office building with full redundancy, so that the office building can operate with a single boiler and a single chiller.

The office building's energy demands for electricity, space heating, and air conditioning throughout 1998 are shown in figures 1 to 5. Figure 3 shows the average power demand and the 15-minute rolling peak of each month in 1998. Figures 1 shows values of this running average hourly usage throughout a typical day in February 1998 during which no electricity was used for air conditioning. For weekdays, the electric demand profile does not vary significantly from day to day, however, weekend day have its own distinct profiles due to reduced building occupancy.

Since no power was consumed by the office building's electric chillers in February 1998, Figures 1 reflects the office building non-air conditioning (non-a.c.) demand. The non-a.c. load characteristics presented in Table 1 are based on the data shown in these demand curves.

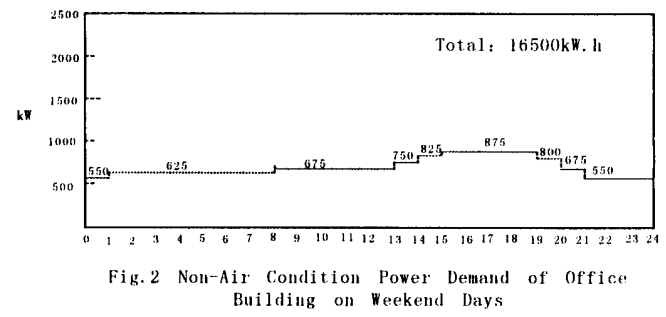

Table 1. Characteristics of Office Building's Non-A.C. Power Demand

\begin{tabular}{|l|l|l|}
\hline & weekendday & weekday \\
\hline Peak load (kW) & 1400 & 2100 \\
\hline averageload (kW) & 700 & 1400 \\
\hline base load (kW) & 560 & 590 \\
\hline
\end{tabular}

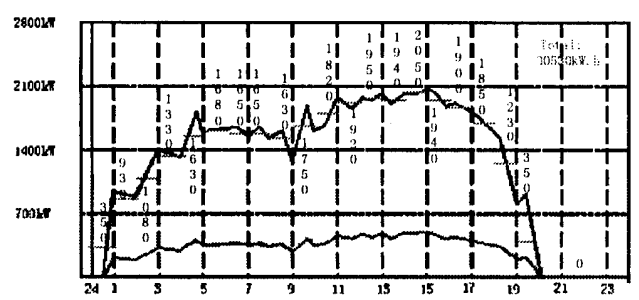

Figure 5. Hourly Air conditioning Deusand of the orfice Building 
Space heating readings from a single gas meter are reported daily. Figure 4 shows a typical hourly average demand pattern of space heating in 1998. The space heating water is supplied at $82-93^{\circ} \mathrm{C}$ and returned at $65^{\circ} \mathrm{C}$ or higher, the boiler efficiency is $80 \%$.

The chiller log provides at 5-minute intervals, the logs indicate that the peak instantaneous operating level in 1998 was $710 \mathrm{~kW}$. The observed peak power demand of building in $1998,2790 \mathrm{~kW}$, was slightly less than the sum of the peak non-a.c. and air conditioning loads $(2200 \mathrm{~kW}+710 \mathrm{~kW}=2930 \mathrm{~kW})$. This is not surprising since the building operators maximized the operating level of air conditioning in the morning, prior to the non-a.c. peak power demand.

The maximum of the daily average air conditioning rates for 1998 was $2100 \mathrm{~kW}$, the office building would require an air conditioning rate of $2600 \mathrm{~kW}$, if the ambient temperature reached extreme of $38^{\circ} \mathrm{C}$ and the relative humidity reached $100 \%$. The existing, electrically driven, vapor compression chiller would require $580 \mathrm{~kW}$ to provide this cooling rate. Figure 5 shows a typical hourly air conditioning demand in office building, the total heat removed from the building on this warm day was $29898 \mathrm{~kW}$.h, the power consumed by the chiller was $6748 \mathrm{~kW}$.h. The corresponding coefficient of performance was 4.5 .

\subsection{A distributed power generation system retrofit to the office building}

The economic analysis of the distributed power generation is carried out in a conventional manner, i.e. by comparing the costs of the distributed power generation system with that of the existing energy supply system. According to the energy demands of the office building, a retrofit power generation energy supply system is designed for the office building that is shown in Figure 6.

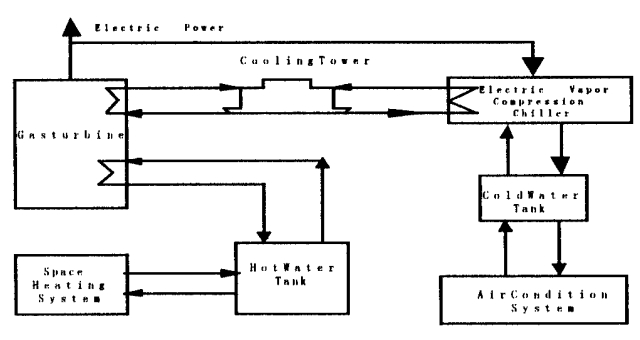

Figure 6. Distrtbuted Geaterationsysten

The distributed Power generation system produces both electricity and heat. The possibility of heat storage is also considered. To meet the electricity and heat demands of the office building and the reliability requirements of energy supply the distributed power generation system is equipped with 4 units of gas engine each rated $700 \mathrm{~kW}$. Operating conditions of these gas engines are show in Table 2

\begin{tabular}{|c|c|}
\hline Electrical power output & $\mathrm{kW}$ \\
\hline Heat output Exhaust gas heat exchanger & $460 \mathrm{~kW}$ \\
\hline acket water & $\mathrm{kW}$ \\
\hline Gas consumption & $213.4 \mathrm{~m}^{3} / \mathrm{h}$ \\
\hline Efficiency & $36 \%$ \\
\hline Water return temperature & $71^{\circ} \mathrm{C}$ \\
\hline Water supply temperature & $85{ }^{\circ} \mathrm{C}$ \\
\hline
\end{tabular}

\subsection{Real time price of grid electricity for commercial}

Table3. Real time price of grid electricity for commercial

\begin{tabular}{|c|c|c|c|}
\hline Voltage range & $\begin{array}{c}\text { Peak load } \\
¥ / \mathrm{kW} . \mathrm{h}\end{array}$ & $\begin{array}{c}\text { Average load } \\
¥ / \mathrm{kW} . \mathrm{h}\end{array}$ & $\begin{array}{c}\text { Base load } \\
¥ / \mathrm{kW} . \mathrm{h}\end{array}$ \\
\hline Voltage $<1 \mathrm{kV}$ & 0.965 & 0.613 & 0.284 \\
\hline $1 \mathrm{kV} \leqq$ voltage $\leqq 10 \mathrm{kV}$ & 0.953 & 0.603 & 0.275 \\
\hline
\end{tabular}

Table3 shows the real time price of grid electricity in Beijing. In 1998 the price of gas is $\$ 0.163 / \mathrm{m}^{3}$. The office building used a total amount of $363828.7 \mathrm{~m}^{3}$ natural gas for space heating. Resulting a total cost of $\$ 1035321.04$ for supplying energy to the office building.

The turnkey cost of gas engine CHP (combined heat and power) unit is $\$ 480 / \mathrm{kW}$ and the O\&M cost is $6 \%$ of turnkey cost. The caloricity 
of natural gas is $32809.73 \mathrm{~kJ} / \mathrm{m}^{3}$. The office building consumed a total amount of 12004MW electricity. The capacity cost of the distributed power generation supply energy system is indicated as follows: capital cost of distributed power generation: $4 \times 700 \times 480=\$ 1344000$

O\&M cost: $\quad 1344000 \times 6 \%=\$ 80640$

Cost of fuel:

$12004000 \times 3600 / 32809.73 / 36 \% \times 0.163=\$ 619363.9$ To assess the economy of this distributed power generation supply energy system, discount rate is taken as $11 \%$ and the life of the energy supply system is assumed to be 20 years. Assessing result is $\$ 0.072 / \mathrm{kW} . \mathrm{h}$.. The total costs for distributed power generation supplying energy to the office building is: $12004000 \times 0.072=\$ 864288$;

It follows that saving made by the distributed power generation supplying energy in comparison with the existing supplying energy system in 1998 is indicated as the following:

$1035321.047-864288=\$ 171033$, $171033 / 1035321 \times 100 \%=16.5 \%$,

The saving rate is $16.5 \%$ 。

\section{Economic optimization model for distributed power generation energy supply system}

Depending on the demand profiles and distributed power generation system, the economic optimization model for distributed power generation energy supply system (DGESS) is formulated and solved by the software called the MATLAB.

The objective of the economic optimization model described here is minimizing the total annual cost, which consists of fixed capacity cost and variable operating cost. The operating cost includes all the purchased energy minus the energy credit from the sale of power to the grid and operation and maintenance expenses.

The yearly requirement is computed based on typical hourly energy demand curve.

$$
Z=Z_{v c}+Z_{f c}+Z_{o m c}--------(1)
$$

$$
\begin{aligned}
& Z_{v c}=\sum_{1}^{r} \sum_{1}^{d} \sum_{1}^{N}\left[\left(\mathrm{P}_{\mathrm{EG}} \times\left(\mathrm{E}_{\mathrm{Gl}}+\Theta \mathrm{N}\right)+\mathrm{P}_{\mathrm{EO}} \times \mathrm{E}_{\mathrm{CG}}+\mathrm{Pfc} \times \mathrm{Fch}\right.\right. \\
& \left.+\mathrm{Pfb} \times \mathrm{Fbl}+\Theta N\left(N_{\text {last }}-N_{0}\right) / \varepsilon_{\text {in }} \times p_{E G i n}\right]-----(2) \\
& Z_{f c}=\mathrm{P}_{\mathrm{CH}} \times \mathrm{E}_{\mathrm{CH}}+\mathrm{P}_{\mathrm{BL}} \times \mathrm{R}_{\mathrm{BL}}+\mathrm{P}_{\mathrm{CC}} \times \mathrm{R}_{\mathrm{CC}} \\
& +\mathrm{P}_{\mathrm{AC}} \times \mathrm{R}_{\mathrm{AC}}+\Theta \mathrm{max} \times \mathrm{p} \Theta-------(3) \\
& Z_{o m c}=\left(\mathrm{kch}+\mathrm{A}_{\mathrm{ch}} \times \mathrm{E}_{\mathrm{CH}} / \mathrm{E}_{\mathrm{CHM}}\right) \times \mathrm{P}_{\mathrm{CH}} \times \mathrm{E}_{\mathrm{CH}} \\
& +\left(\mathrm{k}_{\mathrm{bl}}+\mathrm{A}_{\mathrm{bl}} \times \mathrm{R}_{\mathrm{BL}} / \mathrm{R}_{\mathrm{BLM}}\right) \times \mathrm{P}_{\mathrm{BL}} \times \mathrm{R}_{\mathrm{BL}} \\
& +\left(\mathrm{kcc}+\mathrm{Acc} \times \mathrm{R}_{\mathrm{CC}} / \mathrm{R}_{\mathrm{CCM}}\right) \times \mathrm{P}_{\mathrm{CC}} \times \mathrm{R}_{\mathrm{CC}} \\
& +\left(\mathrm{kac}+\mathrm{Aac} \times \mathrm{R}_{\mathrm{AC}} / \mathrm{R}_{\mathrm{ACM}}\right) \times \mathrm{P}_{\mathrm{AC}} \times \mathrm{R}_{\mathrm{AC}} \\
& +(\mathrm{k} \Theta+\mathrm{A} \Theta \times \phi) \times \Theta \max \times \mathrm{p} \Theta------(4)
\end{aligned}
$$

Notation:

$Z_{v c} \quad$ Variable cost (\$)

$Z_{f c} \quad$ Fixed cost (\$)

$Z_{\text {omc }} \quad \mathrm{O} \& \mathrm{M} \operatorname{cost}(\$)$

$r$ The Number of Seasons

d The Number of Typical Days in One Season

N The Number of Periods of One Typical Day

$\mathrm{P}_{\mathrm{EG}}$ Price of Electricity from Grid (\$/kWh)

$\mathrm{E}_{\mathrm{GI}} \quad$ Electric Power Consumed from Grid (kW)

$\Theta N$ Charge or Release Electric Power in Energy Storage Unit $(\mathrm{kW})$

$P_{E O} \quad$ Price of Electric from DG $(\$ / k W h)$

$\mathrm{E}_{\mathrm{CG}} \quad$ Electric Power Supplied to Grid form DG ((kW);

Pfc Price of Fuel for DG $\left(\$ / \mathrm{m}^{3}\right)$

Fch Fuel Consumption by DG $\left(\mathrm{m}^{3}\right)$

$\mathrm{Pfb} \quad$ Price of Fuel for Boiler ( $\$ / \mathrm{m} 3)$

$\mathrm{Fbl}$ Fuel Consumption by Boiler $\left(\mathrm{m}^{3}\right)$

$\mathrm{P}_{\mathrm{CH}} \quad$ Capacity Cost Coefficient of DG $(\$ / \mathrm{kW})$

$\mathrm{E}_{\mathrm{CH}} \quad$ Electric Capacity of DG $(\mathrm{kW})$

$\mathrm{P}_{\mathrm{BL}} \quad$ Capacity Cost Coefficient of Boiler $(\$ / \mathrm{kW})$

$\mathrm{R}_{\mathrm{BL}} \quad$ Capacity of Boiler ( $\mathrm{kW}$ )

$\mathrm{P}_{\mathrm{CC}}$ Capacity Cost Coefficient of Compression Chiller $\$ / \mathrm{kW})$

$\mathrm{R}_{\mathrm{CC}} \quad$ Capacity of Compression Chiller(kW)

$\mathrm{P}_{\mathrm{AC}} \quad$ Capacity Cost Coefficient of Absorption Chiller (\$/kW)

$\mathrm{R}_{\mathrm{AC}} \quad$ Capacity of Absorption Chiller ( $\mathrm{kW}$ )

$k_{c h}, A_{c h}$ Constant to Cover O\& M Expenses for DG

$k_{b l,} \quad A_{b l}$ Constant to Cover O\& M Expenses for Boiler

kcc, Acc Constant to Cover O\& $M$ Expenses for Compression Chiller

kac, Aac Constant to Cover O\& M Expenses for Absorption Chiller

$\Theta N\left(N_{\text {last }}-N_{0}\right)$ The Dispersion of Energy in Storage Unit for a Optimize Circle 
$k \Theta, A \Theta$ Constant to Cover O\& $M$ Expenses for Energy Storage Unit

\section{$\phi \quad$ Rate of Used for Energy Storage Unit}

$\Theta \max * \mathrm{p} \Theta$ Fixed Cost of Energy Storage Unit

The model has been used to optimize the design and daily operation of the energy supply system. The
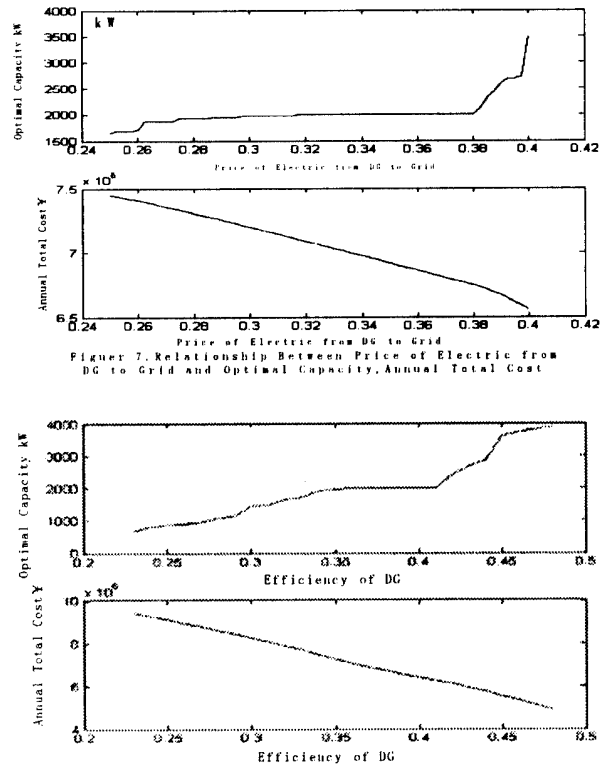

Figual 9. Relationship Betweell Efficiency of DG all Optimal Capacity, Anmual total Cost

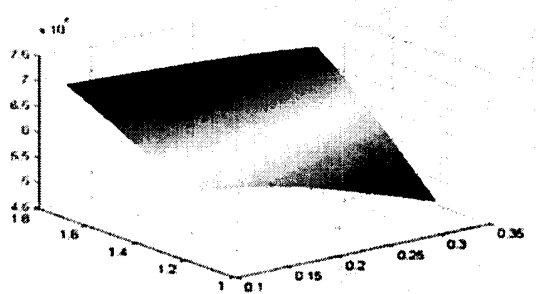

Figuer11. ReationshipBetweenPriceoffuel, Priceof Electricfrom DGito (iridandAnnual Total Cost

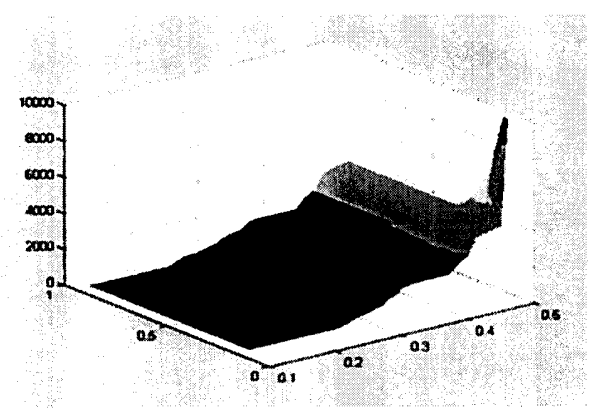

Figuer 13. ReationshipBetweentleat toPowerRate, Priceof Electricfrom[XtoGridandoptimalCapacity analysis can be extended to include variation of prices, device efficiency and other elements, along with other demand profiles as well. Figure 7 to 14 show respectively the influences of electricity sales price from DG to grid, price of fuel, efficiency of DG, heat to power rate of DG and optimal capacity and the total operating cost of DG.
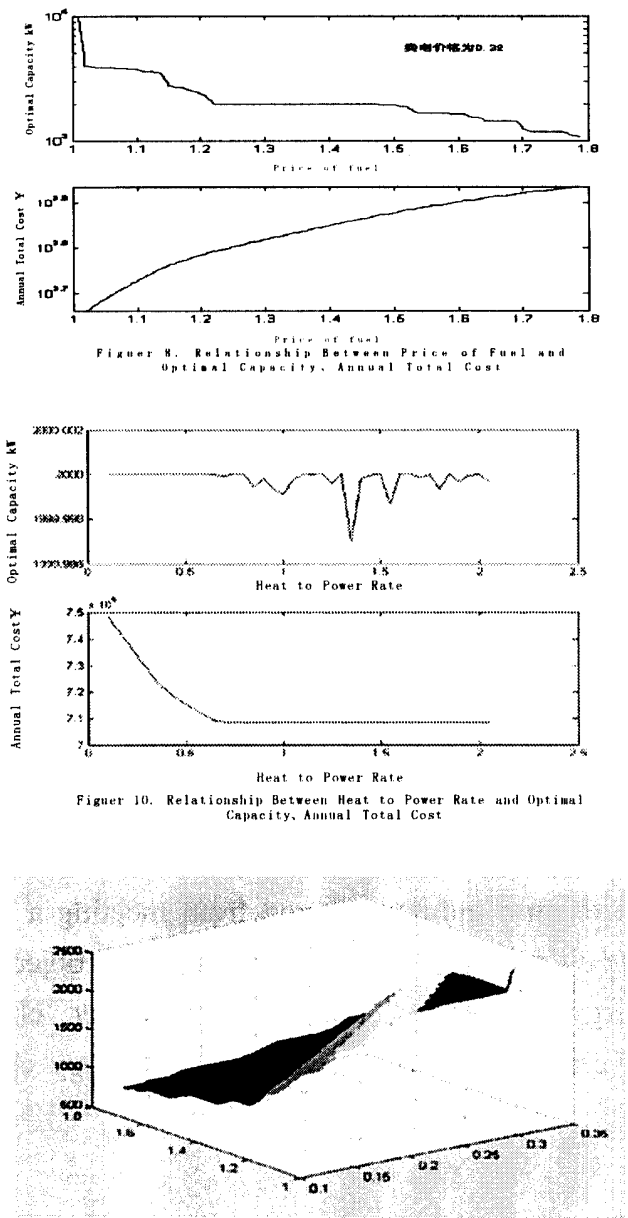

Figuer 12. ReationshipBetweenPriceoffuel, Priceof ElectricfromDGtoliridand0ptimalCapacity

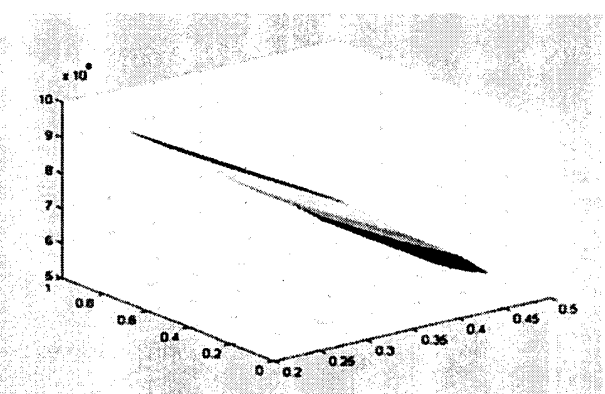

Figuer14. ReationshipBetweenHeat toPowerRate, Price of ElectricfromDGtoGridand Annual TotalCost 


\section{Conclusions}

This paper provides insight into technical and economic aspects of distributed power generation for a office building. It is shown that the feasibility of a distributed power generation energy supply system as the depicted office building, dependences on the local price of electricity and gas and on the system's capital and maintenance cost details. The analysis shows that distributed power generation supply energy for the office building can save total cost about $16.5 \%$ compared with existing energy supply system.

The economic optimization model for distributed energy supply system can be used to optimize the behavior of various items of distributed energy supply system. From the result of optimization, we can see that price of electric from DG to grid, price of fuel and efficiency of DG have a strong impact on optimal capacity and total operating cost of DG. In Beijing, the market price range of power from DG to grid is $0.038-0.045 € / \mathrm{kW}$.h. However, the heat to power rate have a exiguous impact on total operating cost of DG, because the heat energy demand of the office building is relatively insignificant.

The electric industry moved from meeting a basic need for electricity to satisfying the multiple objectives of energy efficiency, reliability, customer choice, market competition, fuel diversity, technology choice and environmental protection. The distributed generation will become a economic and reliable method of applied energy.

\section{References}

[1] Xu Jianzhong. The outlook of distributed power generation and combined heat, cold and power tri-generation. conservation and environment protection, 2002, 3: 10-14

[2] ARI . The role of distributed generation in competitive energy markets. 1999.

[3] H.lee Willis. Distributed power generation planning and evaluation. New York : Marcel Dekker ,2000

[4] David H. Archer, John G. Wimer. A phosphoric acid fuel cell cogeneration system retrofit to a large office building. U.S. Department of Energy Office of Fossil Energy, 1997

[5] J.H.Horlock. Cogeneration-Combined Heat and Power Thermodynamics and Economics. Pergamon. 